\title{
COMPARISON OF THE PLATING AND MICROSCOPIC METHODS IN THE BACTERIOLOGICAL EXAMINATION OF MILK.*
}

\author{
G. W. GOODRICH. \\ (From the Bacteriological Laboratory of the University of Wyoming, Laramie, Wyoming.)
}

Bacterial counts, as a means of milk supply control, have been made but a few years, but in this short time their use has been almost universally adopted.

The plating method, the original method, is today the standard. This wide use has shown it to be open to one very serious objection, in that the incubation period required for the growth of colonies is from 24 to $48 \mathrm{hrs}$. Within this period, under ordinary conditions, the milk should be marketed and consumed. Hence there has been a demand for a simpler and quicker method.

In I905, Dr. Frances H. Slack ${ }^{\mathrm{x}}$ read before the Society of American Bacteriologists a paper giving an account of a method which he had developed for making bacterial counts by means of estimating the number of bacteria in a smear. He gives the following account of his discovery of the method:

"The writer, in carrying out routine examinations of milk sediments for pus and streptococci, noticed that the number of bacteria found in the microscopic field apparently bore a definite relation to the number of colonies developing in the plate from the same sample. It was thought that this might be of practical value if, after prolonged comparison, it turned out to be constantly true, since there would then be no necessity to plate, incubate, and count samples which the microscope alone indicated were better than the legal requirements. . . . . It was decided to test the method thoroughly, comparing the microscopic estimate with the actual count obtained from the plate. This comparison was carried out very carefully with over 2,200 samples, each sample being subjected to the double test-i.e., centrifugalizing and plating, the microscopic estimate being made before the plate was counted, usually within a few hours after the samples were received-and an error of less than I per cent was made in passing as below 500,000 bacteria to the cubic centimeter milks which in the plates showed above this limit. Over a third of the total error occurred in the first 420 samples before the method was fully developed."

Slack used a factor of 10,000 in his estimate of the number of bacteria in a smear. We quote the following, showing how he arrived at this particular number:

"We may say as a rough estimate that each coccus, bacillus, diplococcus, or chain in the $1 / 12$ oil immersion field represents one colony in the $1 / 10,000$ plate from the same sample. The writer wishes to emphasize the fact that this is a coincidence

* Received for publication July 3, 19ז3.

= Technology Quarterly, 1906, 19, p. I. 
stumbled upon in the course of routine work rather than a carefully worked out mathematical result. . It is, of course, impossible to obtain a perfectly even smear, and the sample must be sized up by examining a number of fields. Let the observer find such a representative field, then imagine that instead of looking at a microscopic field through a I/I2 oil immersion lens he is looking at his I/Io,000 dilution plate, and that each coccus, bacillus, diplococcus, or chain within his vision represents a colony on such a plate; and if he will make the plates also, he will find how closely in the main they agree with his microscopic estimate. That is, in most cases the count of a representative field multiplied by 10,000 gives approximately the number of bacteria per cubic centimeter."

Such is the demand for a better method than the plating method for bacterial counts that the microscopic method is beginning to receive official recognition. However, the method has been modified so as to change the factor from Io,000 to 20,000 . Certain firms of instrument makers are manufacturing special centrifuges for this particular work. One of these is in use in the laboratory of the state food chemist at the University of Wyoming.

Since Slack reports his work on the basis of 500,000 bacteria to the cubic centimeter, and since his original factor has been changed, and since, further, he has never published his exact ratio between the counts of the two methods, the writer deemed it worth while to undertake a series of experiments for the purpose of verifying Slack's work and obtaining some data on the reliability of the microscopic count for proving that milk is up to a standard of 100,000 .

The milk samples used in the following tests were taken from cows at the University Stock Farm. Samples were secured in the morning and the microscopic examinations and plates were usually made about 2:00 P.M.

After counting the number of bacteria present in 5 or 6 of the most representative fields and then taking the average of the counts of all these representative fields, this result was multiplied by the 20,000 factor. After various trials it was found that methylene blue was the most satisfactory stain, and this was used in all cases except where otherwise stated.

The tabulations giving the 430 bacterial counts of the two methods, in which the 20,000 factor was used in the microscopic estimation and $a \mathrm{I} / \mathrm{I}, 000$ dilution and 48hour incubation period in the plating method, have been omitted, since all computations have been based on the averages of the counts in groups of 50 . Table I shows the averages of the bacterial counts by groups of $5^{\circ}$, together with the ratio of the microscopic counts to the plate counts.

Even the most superficial examination of Tables $\mathrm{I}$ and 2 shows that there is a close relation between the counts by the plate and by the microscopic method. In Table 3 , where the averages of the groups are compared, this close relation is very apparent. We have worked out the ratio between the averages, dividing the microscopic count by the plate count. These averages throw some light on the problem of whether or not 20,000 is the best factor to use in making the microscopic estimate. Taking the general averages of all the counts, we find that in round numbers the figures 
for the microscopic and plate methods are identical. The resulting ratio of I shows that 20,000 is the best possible number to use for the factor. However, a study of the group averages shows that the ratios greater than I occur in the first three groups, while the remainder are all less than $\mathrm{I}$, the lowest being 0.76 . Allowing

TABLE I.

\begin{tabular}{|c|c|c|c|c|c|}
\hline Group & $\begin{array}{l}\text { No. of } \\
\text { Samples }\end{array}$ & Microscopic & Plate & $\begin{array}{l}\text { Ratio of } \\
\text { Microscopic } \\
\text { to Plate }\end{array}$ & Date \\
\hline $\begin{array}{l}\mathbf{A} \\
\mathbf{B} \\
\mathbf{C} \\
\mathbf{C} \\
\mathbf{D} \\
\mathbf{E} \\
\mathbf{E} \\
\mathbf{F} \\
\mathbf{F} \\
\mathbf{G} \\
\mathbf{G} \\
\mathbf{H} \\
\mathbf{I} \\
\mathbf{I}\end{array}$ & $\begin{array}{l}50 \\
" \\
" \\
4 \\
" \\
" \\
4 \\
30\end{array}$ & $\begin{array}{r}163,000 \\
138,000 \\
86,000 \\
178,000 \\
84,000 \\
83,000 \\
70,000 \\
67,000 \\
82,000\end{array}$ & $\begin{array}{r}1 \mathrm{I} 6,000 \\
134,000 \\
78,000 \\
185,000 \\
91,000 \\
97,000 \\
92,000 \\
83,000 \\
88,000\end{array}$ & $\begin{array}{l}1.40 \\
1.03 \\
1.10 \\
0.96 \\
0.92 \\
0.85 \\
0.76 \\
0.80 \\
0.93\end{array}$ & $\begin{array}{l}\text { Sept. } \\
\text { Sept.-Oct. } \\
\text { Oct. } \\
\text { Nov. } \\
\text { « } \\
\text { Nov-Jan. } \\
\text { Feb. } \\
\text { * }\end{array}$ \\
\hline Gen. average. & $\cdots$ & 107,000 & 107,000 & 1.00 & \\
\hline
\end{tabular}

Groups A and B excluded.

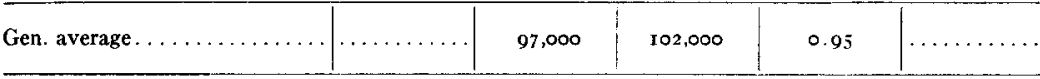

TABLE 2

Showing All the Samples in Which the Ratio of the Microscopic to the Plate Count Was Less THAN 0.5 OR GREATER THAN 2.

\begin{tabular}{|c|c|c|c|c|c|}
\hline Date & Cow No. & Microscopic & Plate & $\begin{array}{l}\text { Ratio } \\
\text { Mic./Plate }\end{array}$ & Group \\
\hline 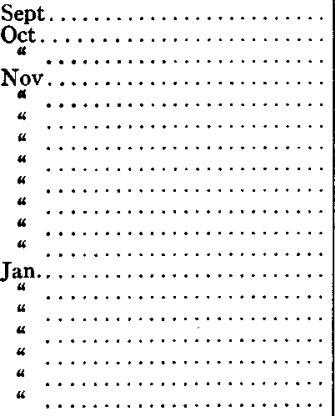 & $\begin{array}{l}162 \\
100 \\
162 \\
134 \\
107 \\
134 \\
134 \\
128 \\
100 \\
128 \\
117 \\
130 \\
100 \\
107 \\
109 \\
117 \\
128 \\
135 \\
136\end{array}$ & $\begin{array}{r}50,000 \\
40,000 \\
100, \infty 00 \\
60,000 \\
100,000 \\
75,000 \\
120,000 \\
55,000 \\
125,000 \\
115,000 \\
100,000 \\
40,000 \\
30,000 \\
60,000 \\
50,000 \\
75,000 \\
40,000 \\
100,000 \\
175,000\end{array}$ & $\begin{array}{r}100,000 \\
100,000 \\
50,000 \\
200,000 \\
25,000 \\
35,000 \\
60,000 \\
125,000 \\
280,000 \\
300,000 \\
200,000 \\
80,000 \\
125,000 \\
150,000 \\
25,000 \\
200,000 \\
80,000 \\
200,000 \\
300,000\end{array}$ & $\begin{array}{l}0.50 \\
0.40 \\
2.00 \\
0.30 \\
4.00 \\
2.10 \\
2.00 \\
0.44 \\
0.41 \\
0.38 \\
0.50 \\
0.50 \\
0.24 \\
0.40 \\
2.00 \\
0.37 \\
0.50 \\
0.50 \\
0.55\end{array}$ & $\begin{array}{l}\mathrm{A} \\
\mathrm{B} \\
\mathrm{C} \\
\mathrm{E} \\
\alpha \\
\alpha \\
\alpha \\
a \\
a \\
\alpha \\
\mathrm{F} \\
\mathrm{G} \\
a \\
a \\
4 \\
" \\
" \\
4 \\
4\end{array}$ \\
\hline
\end{tabular}

for the possibility of greater error at the beginning of the work, due to technic, it has been considered desirable to get the ratio of the average counts after throwing out the first two groups. This ratio is 0.95 , which indicates that the factor 20,000 is a trifle too low. If it is assumed that 0.95 is the true ratio, then $2 \mathrm{I}, 05^{\circ}$ 
would be the correct factor. In view of the small number of data on which the ratio 0.95 is based, together with the small error which that shows in the conventional factor, it is doubtful if anything would be gained by changing it. Altho, as shown in the preceding paragraph, the accuracy of the microscopic method could be but little improved by changing the factor, one must not lose sight of the fact that the milk inspector is concerned with individual samples and not with general averages. To show the variation of the individual counts of the microscopic method as compared with the plate method, Table 2 has been compiled, giving all the samples in which the ratio of the microscopic to the plate count was less than 0.5 or greater than 2 .

TABLE 3 .

Showing Counts Which Differ from the Plate Count by ro,ooo or Less.

\begin{tabular}{|c|c|c|c|c|c|c|c|c|c|c|}
\hline & \multicolumn{9}{|c|}{ GROUP } & \multirow{2}{*}{ TotaIs } \\
\hline & A & B & $\mathrm{C}$ & $\mathbf{D}$ & $\mathbf{E}$ & $\mathbf{F}$ & $G$ & $\mathbf{H}$ & I* & \\
\hline Positives . . . . . . . . . & I 2 & 28 & 36 & 26 & 23 & 18 & 28 & 25 & 25 & $22 \mathrm{I}$ \\
\hline Percentage $\ldots \ldots \ldots \ldots \ldots$ & 24 & 56 & 72 & 52 & 46 & 36 & 56 & 50 & 83 & $5 \mathrm{r}$ \\
\hline
\end{tabular}

* Group I, 30 samples.

The total number of samples in Table 2 is 19 , which is 4.4 per cent of the total number tested. The highest ratio is $2 \mathrm{I}$ and the lowest 0.24 . While these extreme ratios are not so large as to cast any doubt on the correlation of the microscopic to the plate counts, yet if it is considered that the ratios included in Table 2 indicate negative results by the microscopic method then there are 4.4 per cent of negatives, and a method which shows 4.4 per cent negatives should, to say the least, be used with extreme caution. Nor is this percentage of assumed failures lessened if the first two groups are thrown out, for they have only 2 per cent of samples in Table 2 .

It is doubtful, however, in practical milk control, whether all microscopic tests which show a ratio between 0.5 and 2 could be considered as positive. Perhaps the widest variation from the plate count which could be included in the list of positives would be a count not differing more than 10,000 from the plate count. The number of positives found in each group is given in Table 3 . 
A study of Table 3 shows that if this high standard for positive results is adopted the microscopic method must fail, for it appears that according to this standard there are only $5 \mathrm{I}$ per cent positives. Group I, which has the highest percentage of positives, 83 per cent, contains only 30 samples. The highest percentage with full groups of 50 samples is 72 per cent, in Group C. Group A contains the lowest percentage of positives, 24 per cent. If the first two groups be again excluded to lessen the possibility of error, the percentage of positives in the remaining groups gains only slightly over the percentage when all the groups are considered. Total number of positives when groups A and B are excluded is 55 per cent. Since a method which shows only 55 per cent of positive results must be considered a failure, either the standard has been set too high or the microscopic method is not efficient.

The problem of the value of the microscopic count for milk control may be approached from another direction. As milk control is ordinarily carried out some arbitrary standard is fixed and all milk which shows a bacterial count no greater than this standard is regarded as "passed." With this fact in mind a study of the data has been made to determine how often milk samples would have been wrongly "passed," or unjustly "not passed" by the microscopic counts. In making this study two standards were used: first 50,000, and second 100,000. Altho in the control of market milk, standards of 500,000 or higher are used, the samples studied in this paper ran so uniformly low in count that nothing would be gained for the purpose of this discussion by taking a standard higher than 100,000.

Table 4 shows how the microscopic method would have worked in connection with the samples studied, if a count of 50,000 or less had been required for regarding the milk as "passed." Table 5 shows the microscopic method with 100,000 as a standard for passing.

TABLE 4.

\begin{tabular}{|c|c|c|c|c|c|}
\hline Group & $\begin{array}{l}\text { Number of } \\
\text { Samples }\end{array}$ & $\begin{array}{c}\text { Passed by } \\
\text { Both } \\
\text { Methods } \\
\text { Pp }\end{array}$ & $\begin{array}{c}\text { Not Passed } \\
\text { by Both } \\
\text { Methods } \\
\text { Nn }\end{array}$ & $\mid \begin{array}{c}\text { Passed by Plate } \\
\text { but Not by } \\
\text { Microscopic } \\
\text { Method } \\
\text { Pn }\end{array}$ & $\begin{array}{l}\text { Not Passed by } \\
\text { Plate, but } \\
\text { Passed by } \\
\text { Microscopic } \\
\text { Method } \\
\text { Np }\end{array}$ \\
\hline 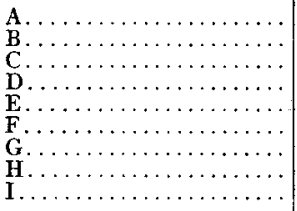 & $\begin{array}{l}50 \\
" \\
" \\
" \\
" \\
" \\
30\end{array}$ & $\begin{array}{r}2 \dot{1} \\
15 \\
10 \\
4 \\
1 \\
0 \\
5 \\
1 \\
0\end{array}$ & $\begin{array}{l}14 \\
30 \\
32 \\
43 \\
38 \\
42 \\
36 \\
38 \\
29\end{array}$ & $\begin{array}{r}\mathrm{I} 4 \\
2 \\
8 \\
\mathrm{I} \\
\mathrm{II} \\
\mathrm{I} \\
0 \\
0 \\
0\end{array}$ & $\begin{array}{r}\text { I } \\
3 \\
0 \\
2 \\
0 \\
7 \\
9 \\
\text { II } \\
\text { I }\end{array}$ \\
\hline $\begin{array}{l}\text { Totals } \ldots \ldots \ldots \ldots \\
\text { Totals exclusive of } \dot{A} \\
\quad \text { and } B \ldots \ldots \ldots \ldots \ldots\end{array}$ & $\begin{array}{l}430 \\
330\end{array}$ & $\begin{array}{l}57 \\
2 \mathrm{I}\end{array}$ & $\begin{array}{l}302 \\
258\end{array}$ & $\begin{array}{l}37 \\
2 \mathrm{I}\end{array}$ & $\begin{array}{l}34 \\
30\end{array}$ \\
\hline
\end{tabular}


The total number of positives $(\mathrm{Pp}+\mathrm{Nn})$ was 359; excluding $\mathrm{A}$ and $\mathrm{B}, 279$. The total number of negatives $(\mathrm{Pn}+\mathrm{Np}), 7 \mathrm{r}$, excluding $\mathrm{A}$ and $\mathrm{B}, 5_{5}$. Percentage of negatives was 16.5 per cent; excluding $A$ and $B, 15.4$ per cent. The total number passed by microscopic method $(\mathrm{Pp}+\mathrm{Np})$ was $9 \mathrm{I}$; excluding $\mathrm{A}$ and $\mathrm{B}$, $5 \mathrm{I}$. The total number passed incorrectly by microscopic method ( $\mathrm{Np}$ ) was 34 ; excluding $\mathrm{A}$ and $\mathrm{B}, 3^{\circ}$. $\mathrm{Np}$ was 37 per cent of $(\mathrm{Pp}+\mathrm{Np})$; excluding $\mathrm{A}$ and $\mathrm{B}, 5^{8}$ per cent. The total number not passed by microscopic method $(\mathrm{Nn}+\mathrm{Pn})$ was 339 ; excluding $\mathrm{A}$ and $\mathrm{B}, 279$. The total number not passed incorrectly by microscopic method (Pn) was 37; excluding $A$ and $B, 21$. Pn was I r per cent of $\mathrm{Nn}+\mathrm{Pn}$; excluding $\mathrm{A}$ and $\mathrm{B}, 7.5$ per cent.

TABLE 5.

Seowing the Working of the Microscopic Method as Compared to the Plate Method in Passing or Not Passing Milk, as Not Being of Higher than roo,ooo Bacterial Count.

\begin{tabular}{|c|c|c|c|c|c|}
\hline Group & $\begin{array}{l}\text { Number of } \\
\text { Samples }\end{array}$ & $\begin{array}{c}\text { Passed by } \\
\text { Both } \\
\text { Methods } \\
\text { Pp }\end{array}$ & $\begin{array}{c}\text { Not Passed } \\
\text { by Both } \\
\text { Methods } \\
\mathrm{Nn}\end{array}$ & $\begin{array}{l}\text { Passed by } \\
\text { Plate, but } \\
\text { Not by } \\
\text { Microscopic } \\
\text { Method } \\
\text { Pn }\end{array}$ & $\begin{array}{c}\text { Not Passed } \\
\text { by Plate, but } \\
\text { Passed by } \\
\text { Microscopic } \\
\text { Method } \\
\text { Np }\end{array}$ \\
\hline 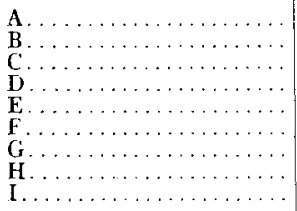 & $\begin{array}{l}50 \\
" \\
" \\
" \\
" \\
" \\
30\end{array}$ & $\begin{array}{l}45 \\
37 \\
38 \\
22 \\
33 \\
31 \\
37 \\
42 \\
26\end{array}$ & $\begin{array}{r}5 \\
\mathbf{1} 2 \\
10 \\
22 \\
12 \\
16 \\
6 \\
0 \\
3\end{array}$ & $\begin{array}{l}0 \\
0 \\
1 \\
3 \\
2 \\
0 \\
0 \\
0 \\
0\end{array}$ & $\begin{array}{l} \\
\\
\mathrm{I} \\
\mathrm{I} \\
3 \\
3 \\
3 \\
7 \\
8 \\
\mathrm{I}\end{array}$ \\
\hline $\begin{array}{l}\text { Totals ............. } \\
\text { Totals exclusive of } \mathrm{A} \\
\text { and } \mathrm{B} \ldots \ldots \ldots \ldots\end{array}$ & $\begin{array}{l}430^{\circ} \\
220\end{array}$ & $\begin{array}{l}3 \mathrm{II} \\
229\end{array}$ & $\begin{array}{l}86 \\
69\end{array}$ & $\begin{array}{l}6 \\
6\end{array}$ & $\begin{array}{l}27 \\
26\end{array}$ \\
\hline
\end{tabular}

The total number of positives $(\mathrm{Pp}+\mathrm{Nn})$ was 397 ; excluding $\mathrm{A}$ and $\mathrm{B}, 298$. The total number of negatives $(\mathrm{Pn}+\mathrm{Np}), 33$; excluding $\mathrm{A}$ and $\mathrm{B}, 32$. The percentage of negatives was 7.6 per cent; excluding $A$ and $B, 7.4$ per cent. The total number passed by microscopic method $(\mathrm{Pp}+\mathrm{Np}$ ) was 338 ; excluding $\mathrm{A}$ and $\mathrm{B}, 255$. The total number incorrectly passed by microscopic method (Np) was 27 ; excluding $A$ and $B, 26$. Np was 8 per cent ( $\mathrm{Pp}-\mathrm{Np})$; excluding $A$ and $\mathrm{B}, 10.2$ per cent. The total number not passed by microscopic method $(\mathrm{Nn}-\mathrm{Pn})$ was 92 ; excluding $\mathrm{A}$ and $\mathrm{B}, 75$. The total number incorrectly not passed by microscopic method $(\mathrm{Pn})$ was 6; excluding $A$ and $B, 6$. Pn was 6.5 per cent of $(\mathrm{Nn}-\mathrm{Pn})$; excluding $A$ and $B, 8$ per cent.

Table 4 shows that with the "passing" standard of 50,000, for the whole number of 430 samples the total number of negatives was 7 r, or 16.5 per cent, and that if Groups A and B were excluded because of error in technic the percentage of negatives becomes I 5.4 per cent. Table 5 shows that with a "passing" standard of 100,000 the percentage of failures in the whole number of counts was 7.6 per cent, and with Groups A and B excluded, 7.4 per cent. 
It is of great importance to the man engaged in practical milk control, who has to face the possibility of carrying his cases to court, to know of a given method how many samples would be unjustly "not passed" out of the total number "not passed." Table 4 shows that, with the samples in question and the passing standard 50,000 , the microscopic method would have unjustly "not passed" 37 out of a total of 339 "not passed," making a percentage of negatives II per cent; if the Groups A and B are excluded the percentage becomes 7.5 per cent. Table 5 shows that if the "passing" standard is 100,000 the percentage incorrectly "not passed" would have been 6.5 per cent, and, if the Groups A and B were excluded, the microscopic method would have shown 8 per cent of negatives.

All this shows that at least where a high "passing" standard is used, injustice would be done by condemning milk on the microscopic count on a single slide. Moreover, it is certain that a method with such a high percentage of negatives would have no standing in the courts. It seems that this method could be used for the control of market milk only when a check was provided by making a number of slides from each sample or by checking all the "not passed" counts by the plate method. The total number incorrectly "passed" as compared to the total number "passed" is not of so much importance as appears at first sight. This is especially true where a comparatively high "passing" standard is used. While from Table 4 with the "passing" standard at 50,000 the number incorrectly "passed" is 37 per cent of the total number "passed" yet it is shown in Table 5 that in lowering the standard to roo,000 the number incorrectly "passed" was reduced to 8 per cent of the total number "passed." Now it is doubtful that a count of 200,000 would be considered dangerous if the "passing" standard be held at 100,000 or even 50,000. When it is remembered in this connection that the highest ratio of microscopic to plate count was found to be but 2. I per cent and that ratio occurred only once in 430 times, it will be seen that the chance of "passing" a milk with a count of 200,000 , when the standard is 100,000 , is extremely small even when it is regarded as "passing" on the microscopic count of a single slide; and with the standard at 50,000 
the chance of "passing" a milk with a count of 100,000 is just as small. So far as is shown by the data of this paper it would be an impossibility to "pass" a milk with a plate count of even 300,000 by using the microscopic method with a "passing" standard of 50,000.

From this the value of the microscopic method in the milk trade is apparent. A milk that is found by experiment to have a microscopic count of say 100,000 or less could be depended upon to be fairly clean milk, while that which did not pass this standard would no doubt be sold as ordinary market milk so that the 8 or 1o per cent unjustly "not passed" would not be a total loss to the producer.

It must not be forgotten that these discussions of the microscopic count are based on the counting of single slides, but if the milk were sampled in duplicate or triplicate it is evident that the counts which checked would be likely to be found more accurate as compared with the plate counts than those studied in this paper.

\section{SUMMARY.}

The results of this work point to the following conclusions:

I. That there is a marked correlation between the plate and microscopic counts.

2. That little, if any, improvement can be made on the factor 20,000 which is used to reduce the microscopic count to terms of the plate count.

3. That the microscopic count from a single slide can be depended upon as being within the limits of one-third as great as three times as great as the plate count.

4. That the microscopic count from a single slide cannot be depended upon as being within I0,000 of the plate count.

5. That the microscopic count from a single slide is not suffciently reliable to warrant the condemnation of market milk, especially when the standard for passing is a low count.

6. That any milk which is "passed" on the microscopic count from a single slide, where the "passing" standard is a low count, is not likely to have a dangerously high count by the plate method. 